NOTES ON THE TYPES OF

\title{
AMERICAN TWO-WINGED FLIES OF THE GENUS
}

SARCOPHAGA AND A FEW RELATED FORMS

DESCRIBED BY THE EARLY AUTHORS

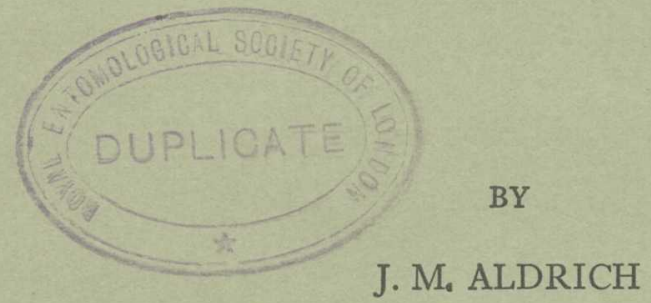

Associate Curator, Division of Insects, United States National Museum

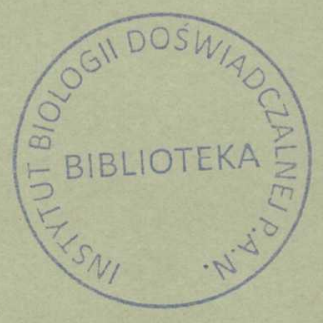

No. 2855. - From the Proceedings of the United States National Museum Vol. 78, Art. 12, pp. 1-39, pls. 1-3

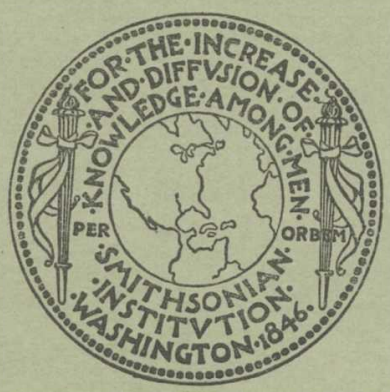

SMITHSONIAN INSTITUTION

UNITED STATES NATIONAL MUSEUM

WASHINGTON, D. C.

1930 
rcin.org.pl 
type material of Macquart, which he generously placed at my disposal.

I was allowed to spread the genitalia of material in Mr. Collin's collection, and in the numerous species in the British Museum, as well as in those received from Vienna.

Dr. Elle Franz, of the Senckenberg Museum, Frankfort on the Main, kindly furnished a list of the types of Wiedemann's Sarcophagas now represented in that institution (phoenicurus, calida, surinamensis); unfortunately only one specimen of each exists, which under the rules can not be loaned.

I was unable to learn the location of any of Rondani's types in the genus Sarcophaga, several inquiries eliciting no response.

In reporting these studies, it seems advisable to list all the species of the early authors, although not all of them have been examined.

In general, no attempt is here made to divide the old genus Sarcophaga into smaller genera, although a few recently proposed genera are mentioned, and others are referred to as groups, leaving their final status for future determination. The present purpose is best served by trying to make the species identifiable, without going very far into the question of subdivision, which would greatly complicate this paper. The genus in the old sense is a very recognizable one, and nearly all the species here mentioned were originally referred to it.

Mr. David G. Hall kindly offered to prepare pen sketches from my penciled ones in my notes, and I am greatly indebted to him for making as good figures as the circumstances permitted. I only regret that he could not draw them from the specimens.

Dr. Harold Morrison, in charge of taxonomic investigations for the Bureau of Entomology, kindly offered the services of Mrs. Eleanor Carlin, of his staff, to make drawings of genitalia in the species received from Vienna too late to send to Mr. Hall. She made all the figures of Plate 3.

\section{SPECIES OF FABRICUS}

Musca occidua, Entomologia Systematica, vol. 4, 1794, p. 315; Systema Antliatorum, 1805, p. 288.-Wiedemann, Auss. Zweif., vol. 2, 1830, p. 368 (Sarcophaga).

Two females in the Zoological Museum, Copenhagen, are in accordance with the current understanding of the species, ${ }^{4}$ but are apparently not types. The species belongs to the genus Sarcophagula Van der Wulp, and has many synonyms.

Musca gulo, Syst. Antl., 1805, p. 283 (Musca).

One female, South America, said to be in the Sehestedt collection, now a part of the Zoological Museum, Copenhagen. The type is

${ }^{4}$ Aldrich, Sarcophaga and Allies, 1916, p. 40. 
still in fair condition, and proves to be the same as my Sarcophaga wiedemann ${ }^{5}$; Townsend ${ }^{6}$ has proposed the new genus Paraphrissopodia with designated type Peckia lamanensis Robineau-Desvoidy, which is again the same species (at least in Townsend's sense, but the type is lost). Townsend saw the type of guto in 1928, and is in accord with the indicated specific synonomy.

Musca tessellata, Syst. Antl., 1805, p. 285.

Sex not mentioned, South America. Smidt and Lund collections.

In the Copenhagen Museum I found three females standing as types; as they showed no striking characters and I was not in a position to compare named material with them, I gave up elucidating the species. From Vienna, however, I have received a good series of both sexes, which are evidently what Wiedemann had when he wrote his description of the species. ${ }^{7}$ There are 22 males and 12 females, seven of the latter on the same pin with a male, presumably taken in copulation. For a wonder it is a nearly homogeneous series, only three belonging to other species. While there is room to doubt the correctness of Wiedemann's identification, I have decided to accept it as authentic, since he saw the types. The specimens are all from the Winthem collection, and from Brazil, five collected by Natterer.

The species belongs to the Oxysarcodexia group of Townsend, and differs from australis Aldrich ${ }^{8}$ so slightly that a figure of the genitalia (fig. 22) and a few comparative notes will make it recognizable. The forceps are distinctly narrower, as viewed from behind; the large lateral plates of the penis are rounded anteriorly, with serrations, not drawn out into a point as in australis; and the tips of the anterior claspers are not nearly so acute, being flattened dorso-ventrally and rounded in that view. Aurifinis Walker is a synonym.

\section{SPECIES OF WIEDEMANN}

IN AUSSEREUROPAISCHE ZWEIFLÜGELIGE INSEKTEN, VOL. 2, 1830

Sarcophaga praeceps, p. 355.

Male, Cuba. I received for study three males from the type lot; the species is the same as indicated by me in Sarcophaga and Allies (1916, p. 23, fig.), and is the type of Macquart's genus Phrissopodia. Sarcophaga chrysostoma, p. 356.

I have reported on the types in Annals Entomological Society of America (vol. 17, 1924, p. 210).

\footnotetext{
${ }^{5}$ Sarcophaga and Allies, 1916, p. 193, fig. 88.

${ }^{6}$ Ins. Ins. Menst., rol. 3, 1915, p. 118.

7 Sarcophaga, in Auss. Zweif., vol, 2, 1830, p. 363.

${ }^{8}$ Sarcophaga and Allies, 1916, p. 282, fig. 135.
} 
Sarcophaga georgina, p. 357.

I received from the Vienna Museum three supposed types, which had been previously seen and reported upon by Böttcher, in Deutsche Entomologische Zeitschrift (1913, page 369), where he asserts that georgina is the same as haemorrhoidalis Meigen. The specimens sent me were two males which Böttcher had labeled haemorrhoidatis, one being from Mexico and the other without locality; and one female from New York, which Böttcher had correctly labeled as falculata Pandelle. But Wiedemann's description is distinctly based on a female from Savannah, which apparently no one has seen since. I reported briefly on the specimens sent me, in Annals Entomological Society of America, (vol. 17, 1924, p. 210) but erroneously mentioned them as four in number. It is probably best to regard the species as a synonym of haemorrhoidalis, at least nothing else can be made of it.

Sarcophaga rubella, p. 357.

Male, Antigua. I saw the type in the Zoological Museum, Copenhagen. The red color seemed to me to be the result of long exposure to light. As I could not spread the genitalia, I made out little else. Sarcophaga chlorogaster, p. 359.

Male and female, from Montevideo and La Plata. The types have apparently not been examined and may be lost; the species is, however, well known from the recognizable description, and is the type of the genus Sarconesia Bigot. See Shannon, Proceedings Entomological Society of Washington (vol. 28, 1926, p. 122), where it is placed in the Calliphoridae.

Sarcophaga plinthopyga, p. 360.

Male, St. Thomas, West Indies. I have discussed the type in Annals Entomological Society of America (vol. 17, 1924, p. 210); I had previously redescribed the species under the name robusta in Sarcophaga and Allies (1916, p. 207, fig.).

Sarcophaga dimidiata, p. 360.

Three males so labeled from the Vienna Museum, "Brasilien. Coll. Winthem." They represent three species, one being an undetermined Sarcophaga, one Notochaeta cognata Walker, and the other also a species of Notochaeta. This last is the only one of the three which has the dark spot between the antennae and orbit which is prominently mentioned by Wiedemann, hence I accept it as type. I refer it to Notochaeta largely on account of the genitalia and of the presence of hairs on the propleura - the last being a character I noted only in August, 1930, in the type species-too late, unfortunately, to apply it in examining most of the types. 
Male.-Front at narrowest (above middle) 0.20 of head width, rather bulging in profile, the sides and parafacials with grayish pollen tinged with yellow. Vertical 1, ocellars normal, frontals 10 pairs, uppermost represented by scars, lowest at base of second antennal joint. The frontal rows diverge gradually from middle, but do not approach orbits. Parafacial bare, wider than third antennal joint; antennae black, third joint twice the second, arista long plumose nearly to tip; facial ridges with only a few hairs above vibrissae; cheek hardly one-third eye height; palpi black; back of head with black hair except just below neck, where the pale pile is somewhat conspicuous.

Thorax grayish pollinose with three black stripes and the usual short one above wing. Chaetotaxy: Dorsocentral 2, 3; acrostichal 0,1 (prescutellar, small); humeral 3 ; posthumeral 1 (inner); presutural 1 ; notopleural 2 ; supraalar 3 ; intraalar 1 ; postalar 2 ; sternopleural 3; scutellum with 2 lateral, 1 subdiscal, no apical. Propleura with a few dark hairs; calypters and rims white.

Abdomen black with slight bluish tinge, pollen thin except on bases and sides of segments and on fourth; first and second segments without median marginals; third with a pair only slightly separated from 4 pairs of lateral marginals; fourth with marginal row of about 14. Genital segments small, black with gray pollen, the first with an interrupted row of about six marginals. Genitalia shown in Figure 25. Forceps brown, black apically, small, parallel, straight, with erect pile on back; accessory plates (outer forceps) dark reddish, shorter than forceps, tapering to a rather sharp black point; penis with large, globose head. First and second of the large abdominal sternites with soft hair and a single pair of long, erect hairlike bristles near apex.

Legs black, front and middle tibiae brown; middle tibia with one bristle on outer front side; tibiae without villosity.

Wings considerably infuscated; epaulet black, basicosta yellow, first vein bare, third setulose about two-thirds of the distance to small crossvein; fourth with rectangular bend and ending not very far before tip of wing; hind crossvein joining fourth vein at twothirds the distance from small crossvein to bend.

Length $10.5 \mathrm{~mm}$.

Sarcophaga rufiventris, p. 362.

I published a note on the Vienna material ${ }^{9}$; a portion of the material under the name was evidently of later origin than the publication of Wiedemann, and I disregarded the single old specimen because I believed it bore the wrong head, glued on. This specimen has come back to me again in the present shipment, from the Vienna

${ }^{8}$ Annals Ent. Soc. America, vol. 17, 1924, p. 211. 
Museum, and I find that the head is authentic, although standing in a suspiciously crooked position with reference to the thorax; careful prying between the two reveals that the joint is normal. The specimen is labeled "Brasilien. Coll. Winthem," and agrees with the description, and I now accept it as the type.

It is entirely distinct from the species identified by me as rufiventris in Sarcophaga and Allies (1916, p. 150), although it runs in my keys directly to that species. It differs from my species in lacking the costal spine and apical scutellars; the front is wider, less bulging, and with fewer frontals; the back of the head has much longer and more abundant pale pile; and the third antennal joint is elongated, more than three times the second (hardly more than second in my species).

Townsend has renamed my species as Rafaelia rufiventris new genus and species, in the Proceedings of the Biological Society of Washington (vol. 30, 1917, p. 45).

The genitalia of the true rufiventris are quite different from those of the other species, but proved extremely difficult to extricate and the penis was lost in the operation. The specimen was in poor condition when received, but it is still possible to make a recognizable description. It must be a rare species, as I have not seen another specimen.

Male (Wiedemann's type).-Front at narrowest (middle) 0.29 of head width; in front view the head is decidedly wider than high. Parafrontals and parafacials rather wide, with pale yellow pollen, the parafacials with only a few small hairs near the orbit. Cheek about two-fifths of eye height, with yellow pollen; scars of five pairs of frontals besides the large upper one, which must have contrasted strongly in size with those next below it; lowest frontals above middle of second antennal joint, not located nearer the orbit than the others. Third antennal joint brownish yellow, long as stated; arista with usual plumosity. Palpi black.

Thorax black in ground color, with a conspicuous whitish stripe above the notopleural suture. Apparently 3 posterior dorsocentrals; sternopleural 3; scutellum with 2 lateral, no apical; propleura bare.

Abdomen rounded transversely (not flattened as in the misidentified species); basal segment blackish, remainder rather clear red and with some whitish pollen; second segment without median marginals; third and fourth each with one pair, well separated from lateral marginals. Genital segments red. Genitalia shown in Figure 27. Forceps red, slender, parallel and well separated, turned backward at base and slightly forward at tip; accessory plate very small; posterior clasper with a very long hair on front side; anterior clasper long, tapering, thin. 
Wings hyaline, first vein setulose on basal half; third setulose nearly to cross vein; bend of fourth rectangular, hind crossvein joining fourth at two-thirds the distance from anterior crossvein to bend. First posterior cell rather widely open; epaulet red.

Legs black, femora stouter than usual; middle tibia with 2 bristles on outer front side; middle femur with small, slanting comb on lower hind side at tip; none of the tibiae with villosity.

Length about $9 \mathrm{~mm}$.

Sarcophaga modesta, p. 363.

One female, from the Vienna Museum, "Brasilien. Coll. Winthem." Agrees with the description and appears to be the type. It agrees throughout with Townsend's Sarcophaga argentea in the Proceedings of the United States National Museum (vol. 43, 1912, p. 358); type of Argoravinia, new genus, in the Proceedings of the Biological Society of Washington, (vol. 30, 1917, p. 190), except that the pollen of the head is slightly yellowish in the Townsend type, a female from Piura, Peru. I believe, however, that the species is the same, as a slight fading in the old Wiedemann specimen would account for the difference. Townsend has correctly placed my Sarcophaga fissa as the male of argentea, in the Proceedings of the Entomological Society of Washington (vol. 20, 1918, p. 20); fissa was described in Sarcophaga and Allies (1916, p. 290, fig.). The wide parafrontals and parafacials, with the setulose first vein, seem to make this a good genus. No detailed description of the female having been published, I offer the following, taken from Wiedemann's type.

Female.-Front wide, at vertex 0.33 of head width, continuing of same width nearly to antennal level. Frontal stripe rather narrow, hardly wider than third antennal joint. Parafrontals and parafacials with smooth white pollen, barely tinged with yellow, the parafacials almost twice as wide as third antennal joint. Cheeks with less dense pale pollen, two-fifths of eye height. Antennae black, second joint reddish at tip, third over twice the second in length; arista normal. Palpi black. Back of head with two rows of black orbital setules above, changing to pale above the level of the lower curve of the eye; remainder of back of head with conspicuous pale hair. Verticals two; ocellars large, orbitals two; one upper frontal large, near eye (scar), the rest of the frontals in five pairs, the rows exactly parallel, lowest pair at base of second antennal joint.

Thorax gray, humerus and stripe above notopleural suture nearly white, other mesonotal stripes faint. Middle of scutellum and hind part of mesonotum with pollen changeable on middle line, light on one half and dark on the other according to the light. Chaetotaxy: Dorsocentral 2, 2 (the posterior are far back, some setules 
between them and suture); acrostichal 0,0 ; humeral 2 (or 3 ); posthumeral 2; notopleural 2; presutural 1; supraalar 3 ; intraalar 2 ; postalar 2 ; sternopleural 3 ; scutellum with 2 lateral, 1 small subdiscal, no apical. Propleura bare. Pleurae white pollinose on upper half and on sternopleura.

Abdomen with rather thin gray pollen, the dark ground showing through; an indistinct median dark stripe and on each side a dark spot on the anterior two-thirds of segments 2-4. No median marginals on segments 1 and 2, 3 with a pair, well separated from the lateral marginals; 4 with row of 8 , large. Genital segments retracted, dark red.

Legs black; middle tibia with 3 bristles on outer front side, the uppermost small.

Wings subhyaline; first vein setulose from humeral halfway to its tip; third setulose about halfway to small crossvein; fourth with rectangular bend, thence straight to costa considerably before apex, the first posterior cell open. Hind crossvein joining fourth vein at last fourth of distance from anterior crossvein to bend. Epaulet and basicosta yellow.

Length $8.5 \mathrm{~mm}$.

Sarcophaga albicans, p. 363.

Two males from the Vienna Museum, "Brasilien, Coll. Winthem." Undoubted types. Brauer and Bergenstamm included the species with two others in their new genus Tripanurga described in Zweiflügler des Kaiserlichen Museums zu Wien (pt. 5, 1891, p. 363), and placed it alone in the genus 2 years later (pt. 6, p. 165); Townsend designated albicans as type of Tripanurga in Insecutor Inscitiae Menstruus (vol. 4, 1916, p. 9).

Tripanurga appears to be a valid genus, the type species resembling Sarcophaga pachyprocta Parker (type of Metoposarcophaga Townsend) in the blunt abdomen with large genital segments, the hairy second vein, the presence of outer verticals in the male, the absence of apical scutellars in the male, and the absence of pale hair on the back of the head except a little below; it differs in the possession of a single pair of proclinate orbitals in the male, and in the absence of anterior acrostichals. It also resembles Sarcophaga sulculata Aldrich (Zygastropyga Townsend) in the shape of the abdomen and absence of acrostichals, but differs in lacking villosity on hind tibiae, the occurrence of orbitals in the male, etc.

Male.-Front at narrowest (below middle) 0.40 of head width; lower front prominent, forming an angle with face. Parafrontals, parafacials, cheeks, and posterior orbits with silvery pollen; the parafacials with only a few slender hairs; inner verticals large, outer two-thirds as long; ocellars normal, upper frontal reclinate 
and strongly differentiated from remainder of frontals, which are in five pairs, the upper minute, the lowest at extreme base of antennae and not farther apart than the preceding pairs; facial ridges bare, converging somewhat at vibrissae, which are at oral margin; Palpi black, cheek two-fifths of eye-height. Antennae black, second joint fully half the third and a little reddish at tip. Frontal stripe mostly overlaid with the silvery pollen of the parafrontals.

Thorax gray, not strongly striped. Chaetotaxy: Dorsocentral 2, 3; acrostichal 2, 0 ; humeral 2 ; posthumeral 1 ; presutural 1; supraalar 3 (only the middle one large); intraalar 2 (far back); postalar 2; sternopleural 1, 1; scutellum with 2 lateral, 1 small subdiscal, no apical. Propleura bare.

Abdomen subsilvery, tessellated, with 3 irregular darker stripes. No median marginals on first and second segments; third with marginal row of 8 small; fourth with larger row of 8 . Genital segments black, large, so that the depth of the abdomen increases from base to tip; the second segment is directly below the first, so that the suture is almost horizontal, and extends considerably forward under the abdomen, fitting closely into the main segments. Genitalia (fig. 24) small, red; forceps united into a small, slender beak; accessory lobes well developed, forming an outer pair of forceps as long as the inner, swollen at base and a little at tip, and fringed with a row of black bristles on the inner side; penis small, tip enlarged forward; posterior claspers slender, with a sharp tip curved forward; anterior claspers flat, narrowing to a sharp tip.

Wing tinged with brown, epaulet black, basicosta red; first vein setulose on basal half (in one specimen there is a strikingly large seta almost at the end of the row, in both wings); third vein setulose less than halfway to the crossvein; fourth vein with rectangular bend, the hind crossvein joining fourth closer to bend than usual, about at the last fifth from anterior crossvein. Costal segment between third and fourth equal to that between auxiliary and first.

Legs black; middle tibia with 2 bristles on outer front side; all tibiae without villosity; no comb on middle femur.

Length $9.5 \mathrm{~mm}$.

Sarcophaga opima, p. 364.

One male from the Vienna Museum, "Brasilien. Coll. Winthem." Agrees with description and is undoubted type. It differs from the genus Sarcophaga, and I would place it provisionally in Notochaeta, although it lacks the hairs on the propleura which occur in the type species. The parafacials are bare, and the notopleura lacks the small bristles which alternate with the two large ones in Sarcophaga. The arista has very long plumosity nearly to the tip; the eye is large, so that the cheek is only one-fourth its height. 
Front 0.25 of head width, the same for almost its whole length; parafrontals and parafacials with golden pollen, the former wider than middle stripe, latter as wide as the rather narrow third antennal joint; cheek and posterior orbit concolorous; back of head with black hair, the pale confined to a small area below neck. Verticals 2 , outer half as long as inner; ocellars minute, proclinate; 7 distinct pairs of frontals, the uppermost one reclinate, not much differentiated from the rest, lowest at base of antennae; the frontal rows diverge slightly below, but do not approach orbits. Facial ridges bare except a few hairs next to vibrissae, which are at the oral margin; palpi black; proboscis small. Antennae black, third joint a little over twice the second, rather slender.

Thorax gray pollinose, tinged with yellow (which is less evident now than indicated by Wiedemann), with three distinct brown stripes and a brown spot on supraalars. Chaetotaxy: dorsocentral 2 , 3; acrostichal 0,0 ; humeral 2 ; posthumeral 1 (inner); presutural 1 ; notopleural 2 ; supraalar 3 (only the middle of any size); intraalar 1; postalar 2; sternopleural 2; scutellum with 3 lateral (middle weak), one small subdiscal, no apical. Calypters white, rim the same.

Abdomen blackish above, the gray pollen thin, on second and third segments confined to a narrow basal region, two submedian stripes not reaching the hind margins, and a lateral basal triangle continuing below; fourth segment gray except on apical half in middle region. First segment without median marginals, second with marginal appressed bristly hairs, third with marginal row of 8 , fourth with row of 12 , of which the outer are small. Genital segments small, first brown with yellow pollen and one pair of bristles, second reddish. Genitalia as in Figure 21. Forceps small, reddish, quite flat, straight, uniformly tapering, the tips black, sharp. Accessory plates (outer forceps) small, narrow, reddish yellow, with sharp tips. Penis in the single specimen strongly bent forward at middle, the stalk yellow, head black, shining. Fifth sternite almost invisible, the three intermediate ones large, with soft hair.

Legs black, tibiae brownish; pulvilli but little enlarged; no villosity on tibiae; middle femur at tip below on hind side with a few short bristles, not however forming a comb; middle tibia with one bristle on outer front side, lower down than usual (at second third).

Wings brown, the color uniform as Wiedemann says. Bend of fourth vein rectangular, with small appendage; first vein bare, third setulose halfway to crossvein. Hind crossvein joining fourth vein at second third of distance between anterior crossvein and bend.

Length $8 \mathrm{~mm}$. 
Sarcophaga comta, p. 365.

Male.-Brazil. Not seen, perhaps not now in Vienna Museum. The description contains several good points-the pollen of the head is white or silvery, except that of cheek, which is almost golden; abdomen reddish, venter yellowish-red, with yellowish hairs. Length $7 \mathrm{~mm}$. A specimen from Vienna labeled "comtae vicina" is Paratheresia claripalpis, but this can hardly be correct, as comta has black palpi.

Sarcophaga phoenicurus, p. 365.

Female.-Brazil, in Frankfort Museum. The single type is still preserved, as I am informed by Dr. Elle Franz, in the Senckenberg. Museum. It has not been seen.

Sarcophaga lambens, p. 365.

Two males and six females received from the Vienna Museum, "Brasilien. Coll. Winthem." All are the same species and apparently of the type series. Some of the types were said to be in the Copenhagen Museum, where I did not see them, as I examined only the Fabrician types there. The series belongs to the very common tropical species described by Townsend as Sarcodexia sternodontis in the Journal of the Institute of Jamaica (vol. 1, 1892, p. 106). According to a manuscript note from Doctor Townsend, the species was also described as Cricobrachia anisitsiana by Enderlein, in the Archiv für Klassifikatorische und Phylogenetische Entomologie (vol. 1, 1928, p. 19), from Paraguay. Townsend saw the Enderlein type. I have discussed the species in Sarcophaga and Allies (1916, p. 265), with a figure of the genitalia; and more recently have analyzed the numerous rearing records in the Journal of Economic Entomology (vol. 20, 1927, p. 590). I referred the species to Sarcophaga in the articles.

Three additional specimens, "Brasilien. Coll. Wiedem.," include one of each sex of the species just mentioned, and one female of varia Walker.

Sarcophaga calida, p. 366.

Female.-Brazil. Not seen. One type is in the Senckenberg Museum, Frankfort. Van der Wulp, in establishing the genus Sarcophagula (Tijdsch. v. Ent., vol. 30, 1887, p. 173), said that the following Sarcophagas of Wiedemann apparently belong in it: calida, surinamensis, terminalis, amata, sugens, obsoleta, and parvula. Brauer and Bergenstamm referred all these species to Sarcophagula without question in their Zweiflügler des Kaiserlichen Museums zu Wien (pt. 5, 1891, p. 414). As I have never made out more than the one species occidua Fabricius as belonging to the genus, the 
species listed are quite likely all synonyms; this is true of parvula and sugens, the only ones I have seen.

Sarcophaga surinamensis, p. 366.

Female and male.-Surinam, in the Senckenberg Museum, Frankfort; one type reported to be still preserved there. Not seen; see note under calida.

Sarcophaga terminalis, p. 366.

Male.-Brazil. Not seen, and apparently no longer preserved in the Vienna Museum. See note under calida.

Sarcophaga amata, p. 367.

Male.-Brazil. Not seen, and presumably not now in the Vienna Museum. See note under calida.

Sarcophaga sugens, p. 367.

Female.-Brazil. Eleven specimens so named were received from the Vienna Museum as types. They are labeled "Brasilien. Coll. Winthem." Of these one male and five females, to which I restrict the species, are Sarcophagula occidua Fabricius, a common tropical American species. Of the others, four are Johnsonia setosa Aldrich. They can hardly have been a part of the original series, which was said to be females, while these are easily recognized as males. The other specimen, a female, is Sarcophaga rapax Walker, or a closely related species. See note under catida.

Sarcophaga obsoleta, p. 367.

Described from one female, West Indies. Not seen, apparently not now in Vienna Museum. See note to calida.

Sarcophaga parvula, p. 368.

One male from the Vienna Museum, "Brasilien," agreeing with the description, in which the sex was not stated. Equals Sarcophagula occidua Fabricius, as expected. See note under catida.

\section{SPECIES OF ROBINEAU-DESVOIDY}

All described in Essai sur les Myodaires, 1830. A few of the descriptions say that the specimen is in the Museum, meaning the Musée National d'Histoire Naturelle in Paris. These types are mostly still in existence. Bigot obtained a few named specimens from Robineau, perhaps types, and several with labels in the handwriting of the latter are now in the collection of $\mathrm{Mr}$. Collin, which includes that of Bigot. I do not know of any other Robineau material now in existence. 
Peckia imperiatis, p. 335.

Male and female, Cuba. Type lost, but it is a very recognizable species; see Aldrich, Sarcophaga and Allies (1916, p. 22), where it is made a synonym of Sarcophaga praeceps Wiedemann, in the genus Phrissopodia Macquart.

Peckia lamanensis, p. 335.

From Lamana, sex not stateà. See note under Musca gulo Fabricius.

Peckia aterrima, p. 336.

Male, Carolina.

Peckia plumipes, p. 336.

Male, Haiti.

Peckia lanipes, p. 336.

Male, Carolina.

Myophora brasiliensis, p. 338.

Female, Brazil. Type said to be in the Museum, but I did not find it there.

Myophora humboldti, p. 338.

Sex not stated, Peru.

Myophora chrysella, p. 339.

Male and female, Brazil.

Myophora flaveota, p. 339.

Female, Brazil. Said to be in the Museum, but I did not find it there.

Myophora therminieri, p. 339.

One female, Carolina, in the Museum. Readily recognizable as the species described by Parker as Ravinia communis. ${ }^{10}$ Walker described it as Sarcophaga anxia, querula, avida, rediviva, aspera, rabida, acerba, and comes; while Thompson described it as paltinervis. These specific names are noted farther on.

Myophora fervida, p. 341.

Female, Haiti.

Myophora viridescens, p. 342.

Female, Nova Scotia.

Myophora cubensis, p. 342.

Sex not mentioned, Cuba.

${ }^{10}$ Proc. Boston Soc. Nat. Hist., vol. 35, 1914, p. 55. 
Myophora consobrina, p. 344.

Male, Philadelphia.

\section{WALKER'S SPECIES}

IN TRANSACTIONS OF THE LINNAEAN SOCIETY, VOL, 17,1837

Sarcophaga Tateralis, p. 352.

One male, St. Paul's in Brazil. Is a Ptitodexia.

Sarcophaga vittata, p. 353.

Not found in British Museum.

Sarcophaga varia, p. 353.

One male, Gorrite Island, off Maldonado, Uruguay. The specimen mentioned as being from Port Famine is not now in the British Museum, the only one found being from Gorrite Island. It is a male, a striking form and easily recognized. Head with golden pile; notopleural stripe golden and a spot on mesopleura and one on pteropleura as well as three almost confluent on sides of abdominal segments two, three, and four, all golden. Mesonotum with three broad black stripes, leaving two narrow yellow stripes besides the notopleural; the yellow stripes continued on scutellum. One vertical; ocellars proclinate; one reclinate frontal, six others to base of second antennal joint. Parafacials with several long hairs irregularly arranged. Cheek almost one-half the eye height. Acrostichal 0, 1; dorsocentral 3, 3 (the first postsutural pair some distance back of suture) ; presutural one; sternopleural 3; scutellum with 2 lateral, no apical. Abdomen rather broad and flat, genital segments large, giving a truncate effect to abdomen; both genital segments black, the first in part golden pollinose and with row of bristles. Genitalia as in Figure 1. Forceps black, flat, the tips blunted and turned a little back. Accessory plate not readily distinguished. Posterior clasper long, curved, sharp; anterior clasper twisted and turned to the side apically in a remarkable way. The penis is thick and bulky and has a wing extending on each side, the right one conspicuously larger than the left and with several claws. Fifth sternite with wide curved opening, a slight lobe at each end projecting noticeably. Hind tibia not villous but with dense depressed hair. Mid tibia almost villous on apical half of flexor side, and with two bristles on outer front side. First vein bare, third with eight to ten hairs. Synonyms are flavicosta Macquart, chilensis Macquart, and nobilis Thomson.

Sarcophaga jejuna, p. 811.

Female, Venezuela. Not found in British Museum. 
Sarcophaga immanis, p. 815.

Female from Honduras. Not found in British Museum.

Sarcophaga stimulans, p. 817.

One female "North America?" Quadrisetosa Coquillett 1901, is a synonym. Redescribed by Hall. ${ }^{11}$

Sarcophaga rapax, p. 818.

One female, "North America?" Heticis Townsend is undoubtedly a synonym of this.

Sarcophaga anxia, p. 818.

One female, North America. A synonym of therminieri RobineauDesvoidy (communis Parker).

Sarcophaga importuna, p. 819.

One female, "North America?" Pachyprocta Parker is a synonym.

Sarcophaga aegra, p. 821.

One female, Massachusetts. It is the same as haemorrhoidalis Fallen, 1816, a very widespread species.

Sarcophaga quemila, p. 821.

One male, "North America?" A synonym of therminieri RobineauDesvoidy (communis Parker).

Sarcophaga avida, p. 822.

One female, Nova Scotia. A synonym of lherminieri RobineauDesvoidy (communis Parker).

Sarcophaga rediviva, p. 823.

One female, St. Martin's Falls, Canada. A synonym of Therminieri Robineau-Desvoidy (communis Parker).

Sarcophaga rabida, p. 823.

One female, Nova Scotia. A synonym of Therminieri RobineauDesvoidy (communis Parker).

Sarcophaga acerba, p. 824.

One female, Nova Scotia. A synonym of lherminieri RobineauDesvoidy (communis Parker).

Sarcophaga aspera, p. 825.

Two females, "North America?" Both are identical with Zherminieri Robineau-Desvoidy, although Walker refers to one as a variety.

\footnotetext{
${ }^{11}$ Annals Ent. Soc. Amer., vol. 21, 1928, p. 346, with figs.
} 
Sarcophaga violenta, p. 826.

One male, Galapagos Islands. Townsend described this species as Gigantotheca galapagensis, new genus and species. ${ }^{12}$ I compared the spread genitalia with those of a Townsend paratype. The accompanying sketches (fig. 2) were made from the Walker type. Head of common Sarcophaga type, the frontal rows diverging below; acrostichals represented by only a small prescutellar pair; posterior dorsocentrals only two far back, the hindmost largest; no marginals on first and second abdominal segments, a row on third. Second genital segment red, the first blackish and bearing a row of six stout bristles on hind margin. Fifth sternite deeply excised as usual, at the bottom of the excision a pair of small protuberances, each with a dense brush of very short, stubby black spines. Genitalia as figured. The forceps are very wide at base, red in color, becoming black about the middle. Viewed from behind they are almost contiguous for some distance, then suddenly spread apart and are parallel to the tips; the contiguous portion is covered behind with fine yellow hair, beyond which are the black bristles shown in the figure. The penis has two median processes on the anterior side, the first black, the second yellow; its tip spreads out in a thin membrane, not well shown in the figure, or better spread out in the Townsend type. The restricted occurrence and the additional characters given by Walker and Townsend should make this easily recognizable.

Sarcophaga vigil, p. 831.

One male, Nova Scotia. Type not found in the British Museum, but the color pattern is so striking that it could hardly be any other species than the one indicated by me in Sarcophaga and Allies (1916, p. 29), in the genus Wohlfahrtia.

Sarcophaga inoa, p. 832.

One female, Galapagos Islands. I did not see the type, but Austen has published notes on it. ${ }^{13}$ He refers it to Brauer and Bergenstamm's "Section Paramacronychia," quite distinct from Sarcophaga.

Sarcophaga anaces, p. 833.

One male, "North America?" Runs to melampyga in Sarcophaga and Allies (1916, p. 107), and agrees in most details, including the erect bristles of the second genital segment, absence of comb on middle femur, etc.; it differs, however, in not having the striking patches of whitish hair on the sides of the scutellum, in having a complete row of marginals on the third abdominal segment, a large

${ }^{13} \mathrm{Ann}$. Mag. Nat. Hist., ser. 7, vol. 19, p. 342. 
upright pair of apicals on the scutellum, and in having the middle pair of marginals of the fourth segment situated at the margin. The genitalia are small and I could not make a satisfactory sketch of them, but the penis has a slender basal segment, the apical part rather globose. As I could not match the species, it remains uncertain whether it is North American.

Sarcophaga ortogesa, p. 834.

One male, Chile. This is the same as Musca chitensis Walker, ${ }^{14}$ of which Phrissopodia splendens Macquart, ${ }^{15}$ is also a synonym. Shannon has made this species the type of the genus Neta. ${ }^{16}$ There are several other synonyms, to be discussed elsewhere. Walker indicated the genus Cynomyia for this species, but seemed to regard it as a subgenus of Sarcophaga.

Sarcophaga proerna, p. 835.

Female.-Montevideo. I did not find the type in the British Museum. The description indicates that it is not a Sarcophaga, but probably something similar to ortogesa.

\section{IN INSECTA SAUNDERSIANA, 1852}

Sarcophaga hirtipes, p. 321.

Colombia. Type not seen in the British Museum. The description indicates a male, but the sex is not stated. The length, $17 \mathrm{~mm}$., with the golden pollen, red genital segments and strikingly villous tibiae, seem to limit the species to Musca guto Fabricus, ${ }^{17}$ of which I saw the type in Copenhagen.

Sarcophaga parva, p. 321.

One male, Para. A synonym of Musca occidua Fabricius, which belongs to Sarcophagula. ${ }^{18}$

Sarcophaga derelicta, p. 322.

One male, now headless, United States. The same as quadrisetosa Coquillett, 1901.

Sarcophaga comes, p. 323.

One male, United States. A synonym of Therminieri RobineauDesvoidy.

Sarcophaga advena, p. 324.

Male and female, Brazil. Not found in British Museum.

14 Trans. Linn. Soc., $\nabla 01.17,1837$, p. 354.

15 Dipt. Exot., vol. 2, pt. 3, 1843, p. 288.

${ }^{16}$ Proc. Ent. Soc. Washington, vol. 28, 1926, p. 123.

I7 Sarcophaga viedemanni Aldrich, Sarcophaga and Allies, 1916, p. 193.

${ }^{18}$ Aldrich, Sarcophaga and Allies, 1916, p. 40.

$2662-30-3$ 
Sarcophaga incerta, p. 324.

One female, Jamaica. Runs to the vicinity of hillifera Aldrich, but I am unable to distinguish several species in the female sex, so can not identify farther.

Sarcophaga aurifinis, p. 325.

One male, Brazil. A synonym of tessellata Fabricius, but the Wiedemann material from Vienna on which I base this conclusion was not received until after the preparation of the plate containing Mr. Hall's reproduction of my figure of aurifinis made at the British Museum (fig. 3).

Sarcophaga cognata, p. 325.

One male, South America. Belongs in Notochaeta, which will be discussed elsewhere.

Sarcophaga fulvivitta, p. 326.

South America, sex not indicated. Not seen in British Museum. Sarcophaga contermina, p. 326.

Brazil, sex not indicated. Not seen in British Museum. Sarcophaga bifrons, p. 327.

One male, South America. Four dorsocentrals, but anterior one very small. First vein bare, third setulose to crossvein; hind tibiae villous; acrostichals only coarse hairs, one pair bristly just before suture. Head ordinary; cheek two-fifths eye height, with pale hairs on lower two-thirds, some black above. Middle femur not with distinct comb. Genitalia (fig. 4) wholly black, the hook at end of penis double and the two long filaments passing between; accessory plate rather long.

Sarcophaga assidua, p. 328.

One male, one female, United States. I greatly misidentified the species in Sarcophaga and Allies (1916, p. 285); my species is ventricosa Van der Wulp, 1896. The Walker types belong to the Chaetoravinia group, but different from all of Mr. Hall's species in his treatise. ${ }^{19}$ Coxae, femora, and tibiae entirely red, tarsi black. First vein setulose only to the little knot next to the bend of the auxiliary (eight setules on each wing). No outer verticals; three pairs anterior acrostichals; four posterior dorsocentrals. Cheek twofifths the eye height, with black hair; palpi almost black. No orbitals in male. A distinct comb present on middle femur; middle tibia with one bristle on outer front side (but there is a smaller above it on one leg). Genitalia as in Figure 5; genital segments yellow, first with a row of bristles. Penis in profile with circular

${ }^{19}$ Annals Ent. Soc. Amer., vol. 21, 1918, p. 331. 
notch in tip, differing from all of Hall's figures. The forceps are reddish-yellow, with distinctly black tip, and the slender prongs of the fifth sternite also have a black tip with a tuft of hairs. I have not seen the species before. The female agrees with the male.

Sarcophaga fulvipes, p. 328.

United States, sex not stated. Not found in the British Museum. There is an earlier Sarcophaga futvipes of Macquart, ${ }^{20}$ hence a new name will be necessary for this species if the types should be found, unless it proves identical with Macquart's species, which is not very unlikely.

Sarcophaga basalis, p. 328.

One male, United States. Described by me as Sarcophaga deceptiva in Sarcophaga and Allies (1916, p. 186).

Sarcophaga pallipes, p. 329.

One female, United States. Legs yellow, four dorsocentrals, first vein bare, mid tibia with two bristles. I can not separate from females of singutaris and several others.

Sarcophaga chrysotelus, p. 329.

One male, South America. Has postscutellum well developed and does not belong to the family Sarcophagidae; will be discussed elsewhere.

IN TRANSACTIONS OF THE ENTOMOLOGICAL SOCIETY OF LONDON, NEW SER., VOL. 4, 1857

Sarcophaga decedens, p. 207.

Male, Colombia. Not found in British Museum.

Sarcophaga subsericans, p. 207.

Male, South America. Not found in British Museum.

Sarcophaga? punctipennis, p. 208.

One male, Colombia. It is a Tachinid with retracted hind crossvein; postscutellum prominently developed; a dark spot on anterior crossvein, one at each end of hind crossvein, and a fourth at bend of fourth vein. Does not run to any genus in my key to forms with retracted hind crossvein. ${ }^{21}$ To be discussed elsewhere.

Sarcophaga injuncta, p. 208.

Female, Brazil. Not found in British Museum.

20 Dipt. Exot., vol. 2, pt. 3, 1843, p. 105.

21 Trans. Amer. Ent. Soc., vol. 52, 1926, p. 9. 
IN TRANSACTIONS OF THE ENTOMOLOGICAL SOCIETY OF LONDON, NEW SHR., VOL. 5, 1860

Sarcophaga intermutans, p. 308.

One female, Mexico, showing no striking characters. Sarcophaga perneta, p. 308.

One male, Mexico. Belongs to the Oxysarcodexia group, and seems unlike any which have been described in recent years. Head with golden pollen; one vertical; ocellars hairlike, small, divergent; two reclinate frontal pairs, seven others to middle of second antennal joint. Antennae and palpi black; cheek over one-fourth the eye height; parafacial with minute hairs. Mesonotum with three heavy black stripes, pollen at sides and on mesopleura yellow; abdomen with distinct, upturned, slender apicals; acrostichals slightly developed before suture, behind damaged; dorsocentral 3, 4; presutural 2; sternopleural 3. Abdomen strongly tessellated, golden on third and fourth segments, the latter mostly red in ground color; fifth sternite imperceptible. Genital segments yellow with golden pollen, first with row of bristles apically. Genitalia as in Figure 6. Forceps slender, yellow to hump, remainder black, narrow in rear view; the globose terminal part of the penis is black. First vein bare, third with about eight setules, no costal spine. Legs black, middle tibia with one bristle on outer front side.

The nearest species known to me is culminata Aldrich, which has a tuft on the back of the penis, etc.

Sarcophaga innota, p. 308.

One female, Mexico, which shows no striking characters.

Sarcophaga conclausa, p. 309.

One female, Mexico, which shows no striking characters.

Sarcophaga despensa, p. 309.

One female, Mexico, not in good condition and showing no striking characters.

Sarcophaga cffrenata, p. 309.

One male, Mexico, agreeing exactly with the description and figures of Sarcophaga adamsi Hall, ${ }^{22}$ which I think without doubt a synonym.

Sarcophaga fortipes, p. 310.

Male, Haiti. Not found in British Museum. The description indicates something in the vicinity of chrysostoma Wiedemann.

\section{SPECIES OF MACQUART}

The collection of Macquart was destroyed, and the only types still existing, as far as I am aware, are those which he stated to be

22 Annals Ent. Soc. Amer., vol, 21, 1928, p. 345. 
in the collection of Bigot (now the property of Mr. J. E. Collin) and in the Museum, meaning the Musée National d'Histoire Naturelle in Paris. Not all of these can now be found, as both collections have suffered somewhat in the lapse of years.

IN HISTOIRE NATURELLN DH DIPTÉRES, VOL. 2, 1835

Phrissopodia brullëi, p. 223.

Male and female, South America.

IN DIPTÈRIS EXOTIQUES, VOL. 2, PART 3, 1843

I give the original pagination, followed by that of the separate edition, more frequently quoted, in parenthesis.

\section{Phrissopodia splendens Macquart.}

Macquart described two species of South American Calliphoridae under this name. The first was in Diptères Exotiques (vol. 2, pt. 3, 1843 , p. 253 (sep., p. 96), pl. 11, fig. 3). It was said to be from Africa, but one specimen was from Chile. The type was in the Paris Museum, but seems to be lost now, as it was not found there by Shannon nor by me. The description and figure leave little doubt that the species is the same one which he described as Calliphora chitensis in the same work (p. 288 (sep., p. 131), pl. 16, fig. 1.) The types were said to be in the Museum and in his own collection. No specimens of chilensis are to be found in the Paris Museum, but in the Bigot collection, now owned by Mr. Collin, I found a series with a Macquart label, presumably the types of this species, as Bigot had many of Macquart's types. It is the same species which Townsend described as Sarconesiopsis caerutea in Insecutor Inscitiae Menstruus (vol. 6, 1918, p. 156) from Peru. Shannon had made out this synonymy from Macquart's description and Townsend's type, and published it (Proceedings of the Entomological Society of Washington, vol. 28, 1926, p. 123).

The second Phrissopodia splendens Macquart was published in Diptères Exotiques, Supplement 4, pt. 2, 1851, p. 204 (sep., p. 231), from Cobija, Bolivia. The type is still in the Paris Museum, and has been seen by Shannon and by me. Shannon erected the genus Neta for this species, on the page of his work above cited. The specific name is antedated by Musca chilensis Waller in the Transactions Linnean Society (vol. 17, 1837, p. 354). I saw the type of this species in the British Museum. It is very striking species, and there are other synonyms.

Enderlein has proposed the new genus Callyntropus in Deutsche Entomologische Zeitschrift (1930, p. 70), designating the first splendida Macquart as type. He gives only a few words of description, but enough to show conclusively that he had before him the 
second species, not the first. He mentions the thickened femora and the strong bushy pilosity of all the legs-characters entirely lacking in the first species. I therefore regard his genus as a synonym of Neta Shannon. If his citation is taken as decisive as against the characters given, it makes Enderlein's genus a synonym of Sarconesiopsis, of which caerulea Townsend (=splendens 1843) is type.

The reported occurrence of the 1843 species in Africa can not now be explained, except as an error of labeling, Enderlein cites the species only from Chile.

Phrissopodia maculata, p. 254 (97) pl. 11, fig. 4.

Male, Cayenne.

Sarcophaga rufipalpis, p. 259 (102).

Male and female, Brazil. Said to be in the Museum, but I did not find it.

Sarcophaga quadrivittata, p. 259, (102), pl. 12, fig. 4.

One male, Para. In Ravinia group, almost the same as my ochracea, ${ }^{23}$ which is a southern species and turns out to be distinct from therminieri in the puparium. Head light golden, thorax with only gray pollen. Abdomen with smooth golden pollen on sides and two rows of oblong gray pollinose spots; extreme tip of fourth and the genital segments red; fifth sternite apparently without brush. Mesonotum with notopleural yellowish stripes and a pair intermediate gray; dorsocentrals apparently three. Sternopleural 1, 1. Legs black, hind tibiae not villous. First vein bare, third with three or four setules.

Sarcophaga flaviceps, p. 260 (103), pl. 13, fig. 3.

Female, near Para, Brazil. Two females, in Museum, each bearing a label by Macquart. One is near sternodontis Townsend, the other similar to ochracea Aldrich.

Sarcophaga rufipes, p. 260 (103).

Male, Chile. Said to be in the Museum, but I did not find it. Sarcophaga chilensis, p. 261 (104), pl. 11, fig. 6.

One male, one female, former with Macquart label, in Museum as stated. A synonym of varia Walker.

Sarcophaga flavicostata, p. 261 (104), pl. 13, fig. 4.

One female, Concepcion, Chile. In Museum as mentioned, and is a synonym of varia Walker, like the preceding.

Sarcophaga cayennensis, p. 262 (105).

Female, Cayenne.

${ }^{23}$ Sarcophaga and Allies, 1916, p. 255. 
Sarcophaga trivittata, p. 262 (105), pl. 13, fig. 3.

Female, Cuba and Mexico. Although he mentions a specimen in the Museum, it is not now to be found there.

Sarcophaga futvipes, p. 262 (105), pl. 12, fig. 5.

Male, Cuba. Said to be in the Museum, but not now to be found there. The unusual color of the legs apparently restricts to a very small number of species, and it is probably identified correctly by me in Sarcophaga and Allies, (1916, p. 182).

Sarcophaga cubensis, p. 263 (106), pl. 12, fig. 6 .

Female, Cuba. There is in the Museum a female without abdomen from the Guerin-Meneville collection, labeled as cubensis. It does not have Macquart's label, and is evidently not the type.

Sarcophaga trigonomaculata, p. 263 (106), pl. 13, fig. 2.

Female, Mexico. Macquart attributes the species to Guerin, who did not publish a description.

IN DIPTERES FXOTIQUES, SUPPLEMENT 1, 1846

Sarcophaga flavifrons, p. 319 (191).

One female, Brazil. In Collin collection; undoubted type, which was said to be in Bigot's collection. The specimen probably belongs to the Oxysarcodexia group, but shows few distinctive characters. Head golden; clypeus cinereous; facial ridges black; dorsocentrals four, the anterior small; first vein bare.

Sarcophaga argyrocephala, p. 320 (192).

Male, Texas. The description gives little indication of the characters.

IN DIPTÈRES EXOTIQUES, SUPPLEMENT 3, 1848

Sarcophaga diversimaculata, p. 214 (54), pl. 6, fig. 4.

Female, Brazil. In Bigot collection. I found the type in $\mathrm{Mr}$. Collin's collection as expected. Cheeks golden, parafacials only yellow, front golden; frontal rows divergent; one large dorsocentral far back, several small; a heavy pollinose yellowish stripe from humerus toward base of wing; a yellowish pollinose spot on mesopleura; pteropleura rather strikingly bare and whitish pollinose on anterior part.

IN DIPTÈRES EXOTIQUES, SUPPLEMENT 4, CONTINUATION, 1851

Sarcophaga rubriventris, p. 208 (235).

One male, Corrientes, Brazil. Type in Museum. Hind tibiae and third antennal joint missing. Dorsocentrals three. Abdomen on disk covered with a reddish substance, probably not natural, not 
reaching sides but reaching front and on third segment almost the hind edge; on fourth segment not extending so near to hind edge. Genital segments wholly black, small, retracted. Hind tibiae not villous; one bristle on outer front side of middle tibia. Costal spine present. First vein bare; third with three or four setules, and beyond cross vein somewhat curved forward so that the first posterior cell is wide in middle.

Sarcophaga rubrianatis, p. 208 (235).

One male, Chile. In Museum, with Macquart label. Hind calypters brown. Pollen not in yellow spots. Dorsocentrals four, only two hindmost large. Genital segments and posterior third of fourth abdominal red; abdomen black with little pale pollen, fifth sternite margined with red. Tibiae not villous.

IN DIPTL̀RES FXOTIQUES, SUPPLEMENT 5, 1854

Sarcophaga notata, p. 128 (108).

Female, South America.

Sarcophaga aureiceps, p. 128 (108).

Female, South America. In Bigot collection. I found the type in Mr. Collin's collection, but it is in very bad condition, and I could make out only that it belongs to the Oxysarcodexia group.

\section{SPECIES OF RONDANI}

IN STUDI ENTOMOLOGICI, TREQUI, VOL. 1, 1848

Sarcophaga circumcisa, p. 76.

Male, Brazil.

IN NUOVI ANNALI SCIENZA NATURALI BOLOGNA, SER. 3, vol. 2, 1850

Sarcophaga pudica, p. 174.

Female, St. Sebastian Island, Brazil.

Sarcophaga varipes, p. 364.

Female, Rio Napo, Brazil.

Sarcophaga pigmea, p. 365 .

Female, Rio Napo, Brazil.

IN ANNUARIO DELLA SOCIRTA NATURALISTI IN MODENA, VOL. 3, 1868

Sarcophaga oralis, p. 26.

Sex not stated, Bahia. Two-line description.

Sarcophaga nurus, p. 26.

"Haemorrhoidalis Mg. non Fall." Occurs in Buenos Aires. Probably the South American specimens so determined were barbata. Thomson; see note under that species. 


\section{SPECIES OF SCHINER}

ALL IN NOVARA REISE, 1868

Sarcophaga dichroa, p. 313.

The material sent me in May, 1930, from the Vienna Museum contained but one specimen bearing this label, but it was evidently not the type, as it did not agree with the description and was dated 1870 (Philippi, Chile, 1870), after the publication of Schiner's work. It appears likely that the single type specimen indicated by Schiner, a female, has been lost. The only reference to the species that I can find is in Brauer and Bergenstamm, in their Zweiflügler des Kaiserlichen Museums zu Wien (pt. 5, 1891, p. 414), where it is listed in Sarcophaga as one of the species seen.

The description states that the species has a black mesonotum with four white stripes; scutellum red at tip; abdomen steel-blue with some pale pruinosity; all femora greatly thickened, the middle ones below with short, regularly arranged bristles, which are absent from the other femora; fourth vein with acute angle at bend, and somewhat bent backward at this angle; all veins bare.

These characters indicate that the species goes in Calliphoridae, probably close to Sarconesia; the femoral characters are peculiar. It should be recognizable from the description, but I have not seen it.

\section{Sarcophaga xanthophora, p. 313.}

Described from one male and four females, from "South America." The series sent from the Vienna Museum now includes two males and three females labeled "Lindig. 1864. Venezuela"; one female of a different species from Brazil; and a male of a different genus from Venezuela, the place being illegible. The Lindig lot is evidently the type series, from which I make the following description:

Male.-Posterior dorsocentrals four, hind tibiae not villous, genital segments red. Front at narrowest (above middle) .22 of head width; pollen of front, face, cheek and posterior orbit deep golden, frontal stripe dark brown; antennae and palpi black; hairs of back of head all black except a few below the neck. One pair verticals; ocellars rather small; upper frontal not differentiated from the following, the frontal rows consisting of about 15 pairs of rather strong and erect bristles, the lowest not diverging to any extent and reaching the middle of second antennal joint. Third antennal joint over twice the second, arista with the usual plumosity on the basal three-fifths.

Mesonotum golden pollinose, with three uniform and distinct black stripes, the middle one extending upon the scutellum, and the usual small, short stripe above root of wing. Chaetotaxy: Dorso- 
central 3,4 ; acrostichal 3,2 ; humeral 3 ; posthumeral 2 ; presutural 2 ; supraalar 3 ; intraalar 2 ; postalar 2 ; sternopleural 3 ; scutellum with 3 lateral, 1 subdiscal, 1 small erect decussate apical; propleura bare, yellow pollinose, as is also the mesopleura.

Abdomen black, with light golden pollen, a broad median black stripe and an irregular changeable one each side. First and second segments without median marginals; third with a depressed marginal row, the middle pair larger; fourth with well-developed marginal row. Genital segments red, the first somewhat dark at base and with marginal row. Genitalia as in Figure 23. Forceps short, flat, distinctly separated, the tips black and prolonged laterally in a slender tooth; accessory plate red, rather broad; claspers black, brown at base, strongly curved; penis blackish, with a large hood, opening anteriorly. Fifth sternite inconspicuous.

Wings subhyaline; first vein bare, third setulose about halfway to crossvein; fourth with rectangular bend, the hind crossvein joining at three-fourths of the distance from small to bend; epaulet black, basicosta yellow.

Legs black; middle tibia with one bristle on outer front side, middle femur with strong comb on lower hind side beginning only a little beyond the middle. All tibiae destitute of villosity.

Female.-Front on upper half .26 of head width, the usual orbitals and outer vertical present. No apical scutellars. Abdomen short, shriveled in types, genital segments golden pollinose on yellow ground. No comb on middle femur.

Length, male, $9.5 \mathrm{~mm}$; female, $8.8 \mathrm{~mm}$.

Sarcophaga truncata, p. 314.

One male, two females, from the Vienna Museum, agreeing with data and description of Schiner; labeled "Novara Reise, Chili." The species is a synonym of Sarcophaga varia Walker.

Sarcophaga amorosa, p. 314.

One male, received from the Vienna Museum, Brazil, undoubted type, as the penis is strikingly bent back out of its usual position, as mentioned by Schiner. The "Borstenbüschel" of the genitalia is, however, only a small group of hairs on the second genital segment.

Belongs to the Oxysarcodexia group, and runs to bakeri Aldrich in my Sarcophaga and Allies, having a pair of apical scutellars and gray pollen on the head. Genitalia as in Figure 26. The penis is so bent back that it appears abnormally long, and spreads the tips of the forceps apart; these tips are narrow and obliquely truncate, the inner side longer. The claspers are longer than in bakeri, as well as the penis. The most obvious difference is in the long, diverging lobes on the front of the penis, which in amorosa 
are completely united above, while in bakeri they are deeply divided on the middle line; this of course does not show in side view, but is striking in the longitudinal. I have seen no other specimens.

Length $6.6 \mathrm{~mm}$.

\section{SPECIES OF THOMSON}

IN EUGENIES RESA, 1869

Sarcophaga occipitalis, p. 532.

One female, Callao, Peru. The species was described as Sarcophaga auribarbata by Townsend, ${ }^{24}$ and later more fully by me as Sarcophaga cotyledonea in Sarcophaga and Allies (1916, p. 187, fig.) It is known to occur in Peru, Brazil, British Guiana, and Guatemala. Townsend has asserted ${ }^{25}$ that only the female of my cotyledonea belongs here, the true male of the species being my capitata (1916, p. 209). I do not agree with his opinion.

Sarcophaga barbata, p. 533.

One female, Honolulu. This is the same species which was described as Sarcophaga falculata by Pandelle, ${ }^{26}$ and which occurs not only in Europe, but in Northern India and widely throughout North America. In 1917 I received Hawaiian material in both sexes from Doctor Illingworth which convinced me of this synonymy, but have withheld publication until Thompson's type could be seen. It is what I supposed. Senior-White ${ }^{27}$ refers to this as "Parker's synonymy," but I believe it must have been communicated in correspondence, as I can not find that Parker ever published it. From the excellent figure, I believe that the same species was described as Sarcophaga argentina by Brethes ${ }^{28}$; he cites also some references to the same species as nurus Rondani, from Argentina.

Sarcophaga dux, p. 534 .

One male, Honolulu. As I expected, this is the same as Sarcophaga harpax Boettcher ${ }^{29} \mathrm{I}$ had received both sexes from Honolulu in 1917 from Doctor Illingworth, which convinced me of the synonymy. Parker has announced the same conclusion. ${ }^{30}$ I did not spread the genitalia of the Thomson type, but have other males from Honolulu in the National Museum which have been spread.

Sarcophaga pallinervis, p. 535.

One male, one female. Undoubtedly the same as Sarcophaga communis Parker, 1914. The oldest name for the species which I found

24 Proc. U. S. Nat. Mus., vol, 43, 1912, p. 357.

25 Proc. Ent. Soc. Wash., vol. 20, 1918, p. 20.

${ }^{2}$ Revue Entom., vol. 15, 1896, p. 185.

${ }^{27}$ Records Ind. Mus., vol. 26, 1924, p. 261.

28 Anales Mus. Nac. Buenos Aires, vol. 28, 1916, p. 142.

29 Deutsche Ent. Zeitsch., 1913, p. 735 .

${ }^{30}$ Bull. Brooklyn Ent. Soc., vol, 14, 1919, p. 41. 
is Sarcophaga Zherminieri Robineau-Desvoidy; $;^{31}$ he described it from Carolina as a Myophora. The identity of communis with pallinervis was well established from Thomson's description, together with specimens of both sexes from Honolulu; it was mentioned by Hall. ${ }^{32}$

Sarcophaga obtusifrons, p. 536.

Two females, Galapagos Islands. These belong to the Oxysarcodexia group, in which females are very difficult or impossible to place. The United States National Museum has a series of two males and six females collected on the Galapagos Islands in 1899, of which the females agree with Thomson's description and types; we may therefore assume with some confidence that the males belong to obtusifrons. They are the same as a series from Samoa identified. by Malloch as taitensis Schiner ${ }^{33}$ where he shows by a figure slight differences between peltata and taitensis, which I had previously decided to be identical. I believe taitensis is correctly identified here by him. Schiner described the species. ${ }^{34}$ It has been customary to give the Novara Reise priority over Eugenies Resa; but Kahl has discussed the point in Annals of the Carnegie Museum (vol. 11, 1917 , p. 393), making out that the latter may have appeared in 1868. Taitensis (including obtusifrons) and peltata are the only species of the Oxysarcodexia group so far known in which the males have any recognizable villosity on the inner side of the hind tibiae. The forceps in peltata are wide in the middle when viewed from behind, while those of taitensis are narrow.

Sarcophaga nobilis, p. 536.

Two females, Montevideo and Buenos Aires; the male mentioned by Thomson not now in the collection. A synonym of varia Walker

Sarcophaga canescens, p. 539.

One female, which is the female of his Tricharaea scatophagina described on p. 541. This is a synonym of Wiedemann's Tachina brevicornis ${ }^{35}$ the type of which I described under the new generic name Mallonotum..$^{36}$ Walker's ?Dexia albicans ${ }^{37}$ is also the same; and Townsend writes me that he also deseribed the genus and species as Leucoravinia quadraticephala. ${ }^{38}$ It results from all this that that species should be known as Tricharaea brevicornis Wiedemann. It belongs to the Sarcophagidae.

\footnotetext{
s1 Myodaires, 1830 , p. 339 .

${ }^{22}$ Annals Ent. Soc. Amer., vol. 21, 1929, p. 331.

${ }^{33}$ Ann. Mag. Nat. Hist., ser. 10, vol. 4, 1929, p. 256.

34 Novara Reise, 1868 , p. 314.

${ }^{35}$ Auss. Zweif. Ins., vol. 2, 1830, p. 299.

${ }^{36}$ Annals Ent. Soc. Amer., vol. 18, 1925, p. 299.

${ }^{37}$ Trans. Ent. Soc. London, n. ser., vol. 4, 1858, p. 204.

ss Wiener Ent. Zeit., vol. 44, 1928, p. 143.
} 
Sarcophaga brevispina, p. 539.

One female, Rio Janeiro. A synonym of Sarothromyia femoralis Schiner, ${ }^{39}$ which was described as a Sarcophila.

Sarcophaga genatis, p. 539.

One female, Brazil. Very nearly identical with Sarcophaga rapax Walker (helicis Townsend) of North America; I could not quite assert that it is the same, not having a male type, and no identified specimens to compare. S. rapax has priority, and it would be best to regard this as a synonym, at least until males from Brazil are found which show differences.

Sarcophaga despecta, p. 540.

One male, Puna (an island in the Gulf of Guayaquil); three females from Panama are different, two of them being Sarcophagula occidua Fabricius, the other, mentioned as a variety by Thomson, having a closed apical and possibly not the same. The male is not in good condition and I could make nothing tangible out of it. In order to dispose of the species, I restrict it to the two females which are the same as occidua.

\section{SPECIES OF YAN DER WULP}

iN biologia centrali-Americana, diptera, vol. 2. AS FAR AS P. 272 this WAS PUBLished IN 1895, THE REMAÍNDER IN 1896

Sarcophaga villipes, p. 269, pl. 7, fig. 2.

One male, three females. This species was described as Sabinata catalina by Parker. ${ }^{40}$ Types of catalina are in the National $\mathrm{Mu}$ seum, and I had a spread authentic specimen with me and compared. it with the spread male type. I misidentified villipes in Sarcophaga and Allies, (1916, p. 178) ; suspecting this, Townsend proposed the name knabi, new species for my specimens. ${ }^{41}$

Sarcophaga rufitibia, p. 270, pl. 7, fig. 3.

Four males. I renamed this species as Sthenopyga globosa in Sarcophaga and Allies (1916, p. 59). It is the type species of Sthenopyga, and does not belong to Sarcophaga.

Sarcophaga vagabunda, p. 270, pl. 7, fig. 4.

Twelve specimens of both sexes. I exclude one female, which is heticis Townsend, and the rest are all stimulans Walker (quadrisetosa Coquillett).

Sarcophaga acanthoptera, p. 271, pl. 7, fig. 5 .

One male, three females. Allied to helicis, having the first vein hairy and three dorsocentrals.

Novara, 1868 , p. 315 .

${ }^{40}$ Bull. Brooklyn Ent. Soc., vol. 16, 1921, p. 112.

$₫ 1$ Proc. Biol. Soc. Wash., vol. 30, 1917, p. 45. 
Male.-Head as in helicis, but outer verticals developed, face more receding, back of head more bulging below. Thorax also the same, but apical scutellars depressed, not decussate. Abdomen more keeled below, with uniform pollen on venter; dorsum quite different, the pollen not so glistening and tessellated, a median stripe and vague hind parts of second and third black, pollen elsewhere slightly yellowish. No median marginals on first and second abdominal segments, third with a pair median and two lateral, fourth with marginal row. Fourth reddish in ground color; first genital segment retracted, apparently dark; second genital red, with a row of short bristles near base. Genitalia as in Figure 7 . Forceps red to about middle, straight and narrow in back view, diverging a little in middle and coming together again. Claspers black, not unusual; penis small, stalked, concave in front and with a pair of small processes. Legs black, mid tibia with two bristles on outer front side, hind tibiae not villous. Wing hyaline, costal spine well developed.

Sarcophaga xanthopyga, p. 271.

Male and female, 17 specimens. Is the same as effrenata Walker. ${ }^{42}$ Sarcophaga conjugens, p. 272.

Two males. Like the preceding, this is a synonym of effrenata Walker.

Sarcophaga stellata, p. 272.

Seven males, two females. I spread the genitalia of all the males, belonging to four species. I restrict the species to three males, from Amula, Omilteme, and Mexico City, which are the same as rapax Walker (helicis Townsend, a common North American species). Of the specimens excluded, one is debitis, one surrubea, and two others are undetermined species but not in suitable condition for designation as types.

Sarcophaga surrubea, p. 273.

One male. A second specimen is one of the cotypes of stellata. Three dorsocentrals, male without villosity on hind tibiae, genital segments red (Group D of Sarcophaga and Allies) ; first vein hairy, tibiae black, first genital segment ordinary; abdomen black except hind margin of fourth segment; penis not flask-shaped (this much runs to couplet 29, Sarcophaga and Allies (p. 116), but it is not my surrubea of couplet 30 ). It is not biseriata nor anything $I$ have seen. Genitalia as in Figure 8, the rows of spines on the lateral lobes of the penis as figured seem very striking.

42. Adamsi Hall, Annals Ent. Soc. Amer., vol. 21, 1928, p. 345, figs. 
As the supposed surrubea of my Sarcophaga and Allies, 1916, (p. 154), is a different species and was not found among the types examined in Europe, I now propose for it the name

\section{SARCOPHAGA MORIONELLA, new species}

Sarcophaga surrubea ALDRICH, Sarcophaga and Allies, 1916, p. 154 (not of Van der Wulp)

Type series, nine males and seventeen females, Havana, Cuba (C. F. Baker).

Type.-Male, Cat. No. 43063, U.S.N.M. Sarcophaga plumigera, p. 273.

Two males, three females. Excluding a male from Teapa, which is fuscianalis and not mentioned from that locality by Van der Wulp. the remainder seem to be a single species, and belong to the genus Notochaeta; they will be considered later under that genus. They are not the same as described by me under Notochaeta in Sarcophaga and Allies (1916, p. 55), and I now propose for the latter, the name

\section{NOTOCHAETA HINEI, new species}

Notochaeta plumigera ALDRICH, Sarcophaga and Allies, 1916, p. 55 (not of Van der Wulp)

Type-Male, Cat. No. 43064, U.S.N.M. from Puerto Barrios, Guatemala (J. S. Hine).

Sarcophaga ventricosa, p. 274.

Two males. This is the species which I erroneously accepted as assidua Walker in Sarcophaga and Allies (1916, p. 285, fig. 137). Sarcophaga diversinervis, p. 274, pl. 7, fig. 7.

One male, one female. I exclude the female, which is a Sarcophaga, and restrict the species to the male, which is a Notochaeta and will be discussed in a later paper.

Sarcophaga fuscianalis, p. 275.

Nine males and females. It is Notochaeta, the same species described by me as Notochaeta subpolita in Sarcophaga and Allies (1916, p. 53), with figure of genitalia.

Sarcophaga praevolans, p. 275, pl. 7, fig. 8 .

Two males, one female. The males are alike, and belong to the Boettcheria group. ${ }^{43}$ The female (Orizaba) is not of this group, and I exclude it.

Male.-Dorsocentrals three, all sternites wide, hind femur with a median row of bristles as in cimbicis, anterior crossvein with

${ }^{43}$ Boettcheria, Parker, Proc. Boston Soc. Nat. Hist., vol. 35, 1914, p. 65. 
a cloud. Pollen of head and abdomen old gold in color; fifth sternite retracted in the spread specimen; no median marginals on second segment; sternopleural 2, 1. Middle tibia with one bristle on outer front side, hind tibia (fig. 9b) with very dense, villous hair on inner side; hind femur attached to trochanter at an angle, trochanter with stubby spines on lower hind edge. Leg more decidely bent at base than in cimbicis, and femur more slender. Forceps from behind (fig. 9a) very distinctive; penis like that of cimbicis as far as I can see.

Enderlein has made this species the type of his new genus Dasyproctia, ${ }^{44}$ but this genus can not be more than a synonym of Boeticheria as it is very close to the type species of the latter, latisterna Parker.

Sarcophaga setulosa, p. 276.

One male. This is a rather small specimen of cimbicis Townsend, ${ }^{45}$ which was fully redescribed by Parker under the name Boettcheria fernaldi ${ }^{46}$ with figures. I have examined types of all.

Sarcophaga turbata, p. 276.

One male, four females. One female (Orizaba) has been correctly set apart by Austen as a different species and I exclude it. The male has three dorsocentrals, hind tibiae not villous, genital segments red; first vein bare; palpi black; anterior acrostichals well developed; and runs to rudis on page 114 of Sarcophaga and Allies, but differs in the genitalia at least. There are one or two slender hairs on the inner side of the hind tibia, suggesting the beginning of villosity. The head and last two abdominal segments have golden pollen; first and second segments with median stripe which hardly extends upon third; third and fourth on venter with long pile, some of which is pale, the fourth black in ground color. Sternopleural 2, 1; scutellum damaged, but at least with good-sized apicals. Cheek over one-fourth eye height; parafacial hairs all minute. Genitalia as in Figure 10. First genital' segment a little brown on sides, with no distinct bristles; second red with a few bristly hairs.

Turbata is designated the type of Dienchaeta new genus by Enderlein $(1928, p .16)$; unfortunately I did not have his paper at hand and can not confirm the existence of the principal character he uses to define the genus - the presence of two pairs of lateral scutellars.

Sarcophaga trivialis, p. 277.

Seventeen males, nine females. I spread the genitalia of all males, and sorted them into ten species. One belong to the Boett-

${ }^{44}$ Arch. f. Klass. u. Phyl. Ent., vol. 1, 1928, p. 23.

${ }^{45}$ Canad. Ent., vol. 24, 1892, p. 126.

${ }^{46}$ Proc. Boston Soc. Nat. Hist., vol. 35,1914 , p. 72. 
cheria group, two to the Ravinia, the other seven to the Oxysarcodexia. I restrict the species to three males of the last-named group from Amula and one from Atoyac, so indicated in the collection; four females from Amula are presumed to be the same.

Mate.-Runs to bakeri in Sarcophaga and Allies (1916, p. 247), differing chiefly in having the forceps close together to tip. Like bakeri, it has a pair of distinct apical scutellars, which do not occur in many of the group. Pollen of head yellow, abdomen with deep yellow pollen on fourth segment, more gray basally. Fifth sternite small, not prominent, yellow, divided into two slightly swollen lobes. Genitalia as in Figure 11. The forceps with an oblique toothlike tip as seen in profile.

Sarcophaga uncata, p. 277.

Three males. Excluding one male from Northern Yucatan, which is caridei Brethes (angustifrons Aldrich) and restricting the species to the other two, it is the same as my marginata, ${ }^{47}$ which sinks as a synonym.

Sarcophaga errabunda, p. 278.

Seven males. I exclude two specimens of sternodontis (Teapa and Chilpancingo), and one belonging to the Acridiophaga group (Amula); the other four are all one species, to which I restrict the species. It is well described and figured by Hall under the name reinhardii. ${ }^{48}$

Sarcophaga pusiola, p. 278.

One male, three females. I exclude two females (Tepetlapa, Orizaba) which have the first vein setulose. The male and the other female, both from Mexico City, to which I restrict the species, are the same species described as Ravinia peniculata by Parker. ${ }^{49}$ I compared a specimen of peniculata determined by Parker.

Sarcophaga debilis, p. 279.

One male, three females. Two of the latter are Sarcophaga rapax Walker, and I exclude them, restricting the species to the others, which are close to rapax but less silvery; the male shows good genitalic differences, while the female has the genital segments blackish and pollinose. Genitalia as in Figure 12. Forceps yellow to tip, flat behind, blunt, small. Penis with short stalk, and large, complicated, globose head. A second male of debitis is found among the cotypes of stellata.

47 Sarcophaga and Allies, 1916, p. 136.

${ }^{48}$ Annals Ent. Soc. Amer., vol. 21, 1928, p. 346.

49 Proc. Boston Soc. Nat. Hist., vol. 35, 1914, p. 21, figs. 
Sarcophaga micropyga, p. 279.

Six males. One I exclude as a different species, restricting the species to the other five. A species of Notochaeta, to be considered in a later paper.

Sarcophaga claripalpis, p. 280.

One male, four females. One female I exclude, a species of Sarcophaga; the remainder do not belong to the Sarcophagidae, but are the species described by Townsend as Paratheresia signifera. ${ }^{50}$ I have discussed the habits, distribution, and in part the synonomy, under Townsend's name. ${ }^{51}$

Sarcophaga sueta, p. 281

Three males, of which I spread two. It is the same species which I described later as Sarcophaga communis, var. ochracea. ${ }^{22}$ Hall recognized it as a distinct species under the name Sarcophaga ochracea..$^{53}$

Sarcophaga tridens, p. 281.

Six males, one female. The males are the same as uncata Van der Wulp. I spread four, the two unspread males and the female are apparently the same.

Sarcophaga deleta, p. 282.

One male, new to me. Dorsocentral three, first vein bare, genital segments red, hind tibiae not villous; anterior acrostichals well developed; an apical scutellar on one side, none on the other; middle tibia with one bristle on outer front side. Genitalia (fig. 13) very characteristic; the forceps black, divergent, strongly curved forward, with a black lateral process near base, and a row of backwardly directed stiff spines at the basal limit of the black part; a similar tuft standing out from the tip of the lateral process.

Sarcophaga tenuiventris, p. 282.

Two males. The same as ventricosa Van der Wulp (p. 274) (assidua Aldrich, not Walker).

Saracophaga oberrans, p. 283.

One male, two females. Both females belong to Notochaeta micropyga and I exclude them, restricting the species to the male. It belongs to the Acridiophaga group, but seems distinct from those described by me. The forceps are as in marginata, but the penis in its last joint has no appreciable side pieces at all, being in the form of a tapering tube with slight lateral protuberances. Dorsocentrals four,

${ }^{50}$ Journ. New York Ent. Soc., vol. 23, 1915, p. 65.

51 Proc. Ent. Soc. Wash., vol. 31, 1929, p. 33.

52 Sarcophaga and Allies, 1916, p. 255, fig. 121.

${ }^{53}$ Annals Ent. Soc. Amer., vol. 21, 1928, p. 340, figs. 
but the second small, 'so it may go in the section with three, as the other Acridiophagas do. Anterior acrostichal of quite striking length; apical scutellars long, decussate, a little upcurved; second abdominal without median marginals, one pair on third; fourth abdominal largely red in ground color. Genitalia as in Figure 14. Runs in the keys in Sarcophaga and Allies to couplet 22 (p. 115), if considered to have three dorsocentrals, and to couplet 13 (p. 246), if considered to have four.

Sarcophaga triplasia, p. 283, pl. 7, fig. 10.

One male, three females. One female (Amula) has been indicated as distinct by Major Austen. Excluding this the others seem to be alike, and are the variety of fulvipes with black legs, described by Parker as fulvipes var. dissidia. ${ }^{54}$ Although the status of fulvipes Macquart is a little uncertain, the close resemblance of the present form to the species as identified by authors seems to justify calling this a variety of it.

Sarophaga tripartita, p. 284.

One male. The same as Sarcophaga plinthopyga Wiedmann, 1830.55

Sarcophaga pexata, p. 284.

Four males, one female. Excluding two males of a different but related species, I restrict the species to two males from Yucatan. The female is probably a third species. As restricted the species fits into the Paraphrissopodia group of Townsend, with hillifera, etc. The nearest form in genitalic structure is otiosa Williston, which however has much longer and narrower forceps, and lacks the first pair of processes on the front side of the penis. Figure 15 shows the structure in pexata.

Sarcophaga volucris, p. 285.

Two males, of two species, both with striking genitalia as different as possible. One (Teapa) is occipitalis Thomson (cotyledonea Aldrich, auribarbata Townsend), and I exclude this, restricting the species to the other, from Atoyac. There are four or more dorsocentrals, only the hindmost two of normal size; hind tibiae thinly but evidently villous both sides; genital segments red; first vein bare; no anterior acrostichals; sternopleurals three; apical scutellars small but distinct. Back of head with two rows of black hairs below, three above. Second abdominal segment without median marginals, third with one pair; fourth segment yellow in ground color

${ }^{54}$ Canad. Ent., vol. 49, 1917, p. 157 , fig.

${ }^{5}$ Robusta Aldrich, Sarcophaga and Allies, 1916, p. 268 ; syn. by Aldrich, Annals Ent. Soc. Amer. vol. 17. 1924, p. 210. 
on apical half. Middle tibia with long villosity from before middle, and one bristle on outer front side.

Genitalia (fig. 16) large; forceps black, large, strongly curved, with dense retrorse, short hair behind, a few more bristly near tip, which is suddenly reduced to a small curved thorn; penis red, long, with a large apical hook directed forward. I have not seen this species before; it will be easily recognized from the genitalia.

Sarcophaga ochripyga, p. 285.

Two males, four females. A male from Frontera and a female from Tepetlapa were set apart by Doctor Townsend on his recent visit and both labeled "Oxysarcodexia obtusifrons Thomson." This species was described from two females, locality Galapagos Islands, and is with little doubt the same as Sarcophaga taitensis Schiner, the latter having priority as generally considered of one year. Schiner's species has not as yet been definitely identified from other regions than the islands of the Pacific, hence I doubt Townsend's identification. I therefore restrict the species to the other male, of which my austratis is a synonym. ${ }^{56}$

Sarcophaga aequata, p. 286.

Two males of two species. I exclude the one from Teapa, which is nearly related to amoena Aldrich, and restrict the species to the one from Amula, which is a species new to me.

Male-Hind tibia with four or five short, slender villous hairs, hardly could be called villous at all; genital segments red; dorsocentral four (or five). Head light golden pollinose; front narrow above; antennae and palpi black; mesonotum with three distinct black stripes and four golden ones; abdomen golden on sides, tessellated; second abdominal segment without median marginals, third with a pair. Middle tibia with one bristle on outer front side. Acrostichal hairlike, but a little coarse. Genitalia as in Figure 17. The peculiar forceps should be instantly recognizable; they are black and have three spines as shown. The accessory plate (outer forceps) is black apically, while the penis is yellow dorsally, brown ventrally.

Sarcophaga afficta, p. 286.

Nine males, one female. Apparently all the same species. Another male, from Rio Paragai, Guerrero, and not listed by Van der Wulp, has a type label, but is a different species. I disregard this specimen. The species belongs to the Oxysarcodexia group, with genitalic characters different from all known to me. The fifth sternite produced in two long, slender, parallel arms, about as in timida but more slender. The forceps viewed from behind are wide and con-

${ }^{56}$ Sarcophaga and Allies, 1916, p. 282, fig. 135. 
tiguous at tip, and have a distinct concavity behind in the middle, not reaching the sides; they are yellow, and at tip there is a transverse black flattened diagonal margin, from about the middle of which on each side a minute tooth projects backward. See Figure 18. I can not match this species in the United States National Museum.

Enderlein has designated this species as type of his new genus Ctenoprosballia. ${ }^{57}$ It seems to me that the genus is a synonym of Oxysarcodexia Townsend, and this has not much more than group standing.

\section{WILLISTON'S SARCOPHAGAS}

IN TRANSACTIONS OF THE ENTOMOLOGICAL SOCIETY OF LONDON, 1896

\section{Sarcophaga micropygialis, p. 363.}

Nine males. Postsutural dorsocentrals four; hind tibiae not villous; genital segments black; first vein bare; middle femur not with comb; cheek with pale beard before the metacephalic suture. These characters come out at servilis Aldrich on page 236 of Sarcophaga and Allies, but the species is distinct on genitalic characters. Genitalia as in Figure 19. The penis is yellow, slender, elbowed, and greatly surpasses the forceps, which are small, blackish, flat behind, the apices narrow and not divaricate.

Sarcophaga concinnata, p. 364.

Three males, one female. As Williston says, this is just like otiosa except in not having villosity on hind and middle tibiae, and in being smaller. I was surprised to find that the similarity extends to the genitalia, which seem identical. It is doubtful if this can be regarded as more than a variety of otiosa.

Sarcophaga otiosa, p. 364.

Three males, one female. Williston retained a pair of the cotypes, which ultimately passed to the American Museum of Natural History, where I found them and published a description in Sarcophaga and Allies (1916, p. 213, fig. 101). My sketch of the genitalia was a poor one, and I here add in Figure 20 one which is a little better. The species is close to pexata Van der Wulp, but the forceps are much more slender with the outer concavity very small, and the penis lacks the first pair of anterior appendages occurring in the latter. Sarcophaga pavida, p. 365.

Two males, one female. A synonym of sternodontis Townsend, a very widespread tropical and subtropical species; I redescribed it in Sarcophaga and Allies (1916, p. 265, fig. 127). In the Williston

\footnotetext{
${ }^{67}$ Arch. f. Klass. u. Phyl. Ent., vol. 1, 1928, p. 28.
} 
types the pollen of the frons is yellow, not so deep golden as in some specimens, but about as in the type of sternodontis.

Sarcophaga chaetopygialis, p. 366.

Numerous specimens, of two species. I restrict the species to the one described by me from a series of cotypes in the American Museum of Natural History, ${ }^{58}$ which is represented here also. It belongs to the Oxysarcodexia group, and is the only one of these known which has hairs on the first vein, there are usually only two or three of these hairs or setules.

\section{EXPLANATION OF PLATES}

\section{Plate 1}

Figure 1. S. varia Walker. $a$, penis, from behind; $b$, male genitalia, from side 2. S. violenta Walker. $a$, genitalia, from side; $b$, forceps, from behind.

3. S. aurifinis Walker. Penis, from side.

4. S. bifrons Walker. Genitalia, from side.

5. S. assidua Walker. $a$, genitalia, from side; $b$, forceps, from behind; $c$, tip of penis, from side; $d$, fifth sternite.

6. S. perneta Walker. Genitalia, from side.

7. S. acanthoptera Van der Wulp. Genitalia, from side; and forceps, from behind.

8. S. surrubea Van der Wulp. a, genitalia, from side; $b$, penis, from behind.

9. S. praevolans Van der Wulp. a, forceps, from behind; $b$, hind tibia of male.

10. S. turbata Van der Wulp. $a$, genitalia, from side; $b$, forceps, from behind.

11. S. trivialis Van der Wulp. $a$, penis, from side; $b$, forceps, from side; $c$, forceps, from behind.

\section{Plate 2}

12. S. debilis Van der Wulp. $a$, genitalia, from side; $b$, forceps, from behind.

13. S. deleta Van der Wulp. $a$, forceps, from behind; $b$, penis, from side; $c$, forceps, from side.

14. S. oberrans Van der Wulp. a, terminal joint of penis, from behind; $b$, genitalia, from side.

15. S. pexata Van der Wulp. $a$, genitalia, from side; $b$, forceps, from behind.

16. S. volucris Van der Wulp. $a$, genitalia, from side; $b$, forceps, from behind, less magnified.

17. S. aequata Van der Wulp. Genitalia, from side.

18. S. afficta Van der Wulp. $a$, genitalia, from side; $b$, forceps, from behind.

19. S. micropygiatis Williston. $a$, genitalia, from side; $b$, forceps, from behind.

20. S. otiosa Williston. $a$, genitalia, from side; $b$, forceps, from behind.

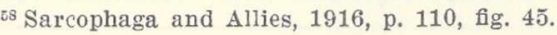


Plate 3

Each figure shows the male genitalia from left, with a rear view of the forceps at the right. All drawn by Mrs. Eleanor A. Carlin.

Figube 21. S. opima Wiedemann.

22. S. tessellata Fabricius.

23. S. xanthophora Schiner.

24. Tripanurga albicans Wiedemann.

25. S. dimidiata Wiedemann .

26. S. amorosa Schiner.

27. S. rufiventris Wiedemann.
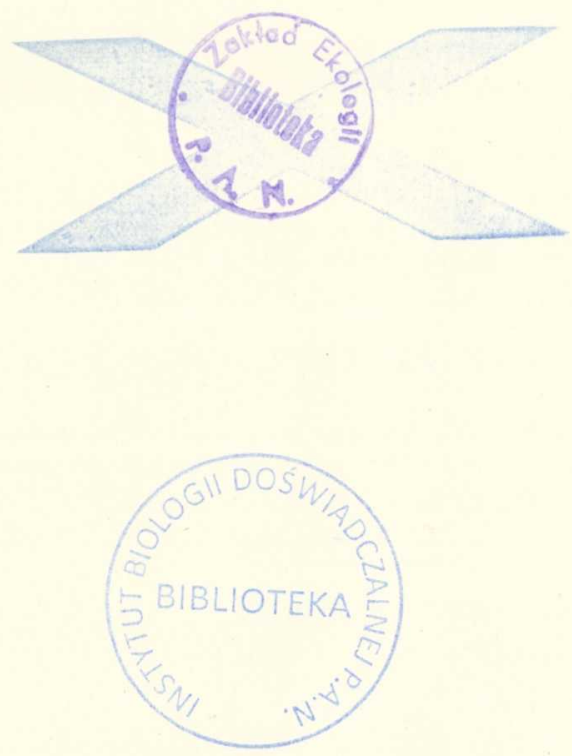
rcin.org.pl 
U. S. NATIONAL MUSEUM
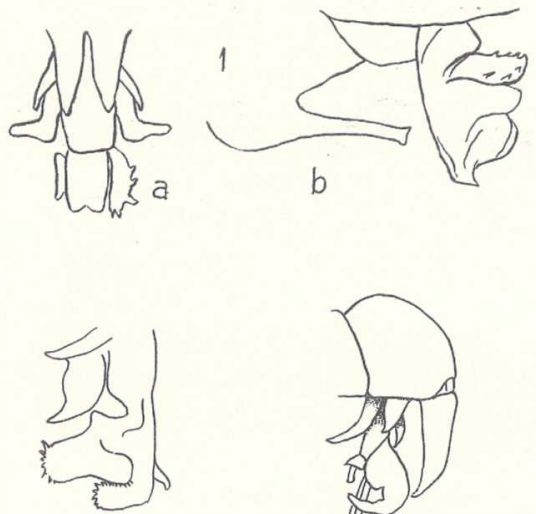

3

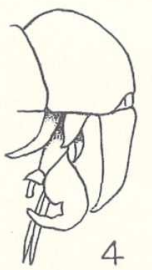

PROCEEDINGS, VOL. 78 ART. 12 PL. 1
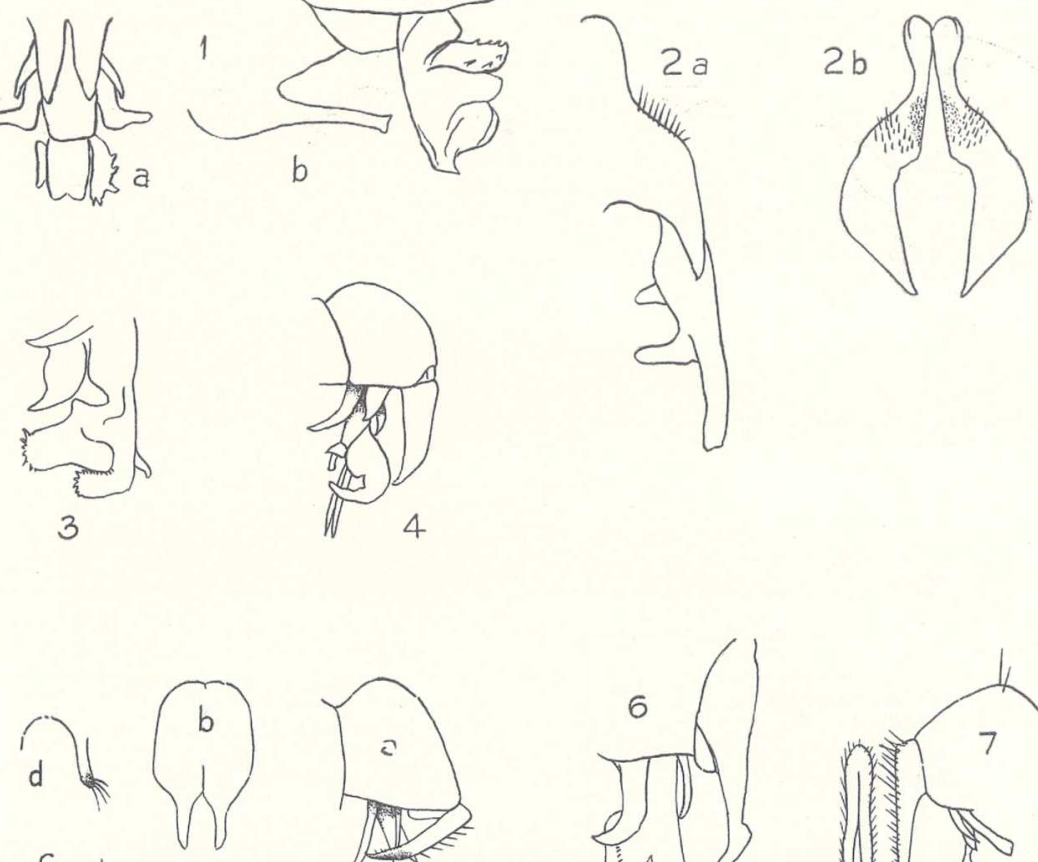

(c)

5
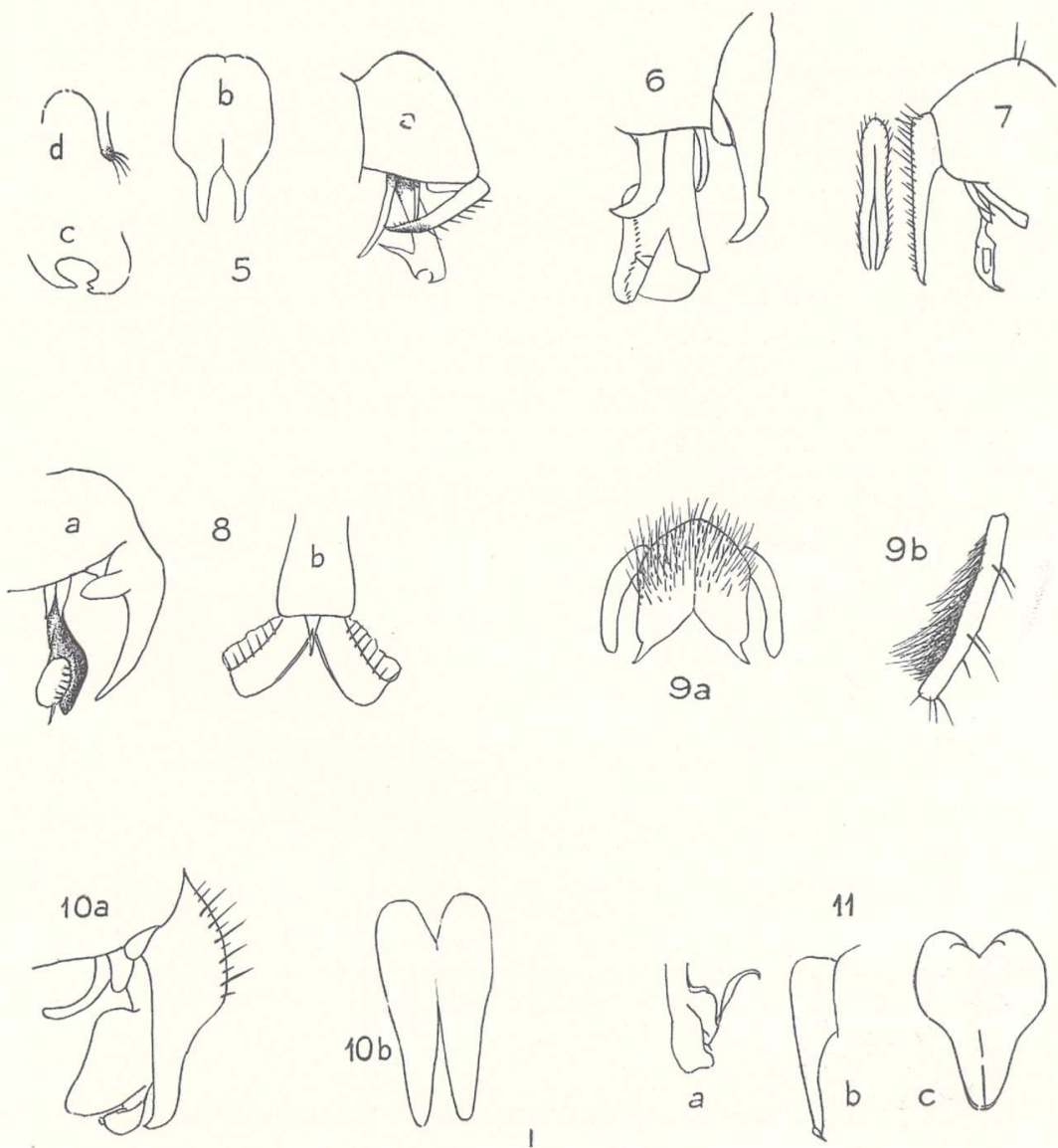

GENitAliA OF FliES OF THE GENUS SARCOPHAGA

FOR EXPLANATION OF PLATE SEE PAGE 38. 
U. S. NATIONAL MUSEUM
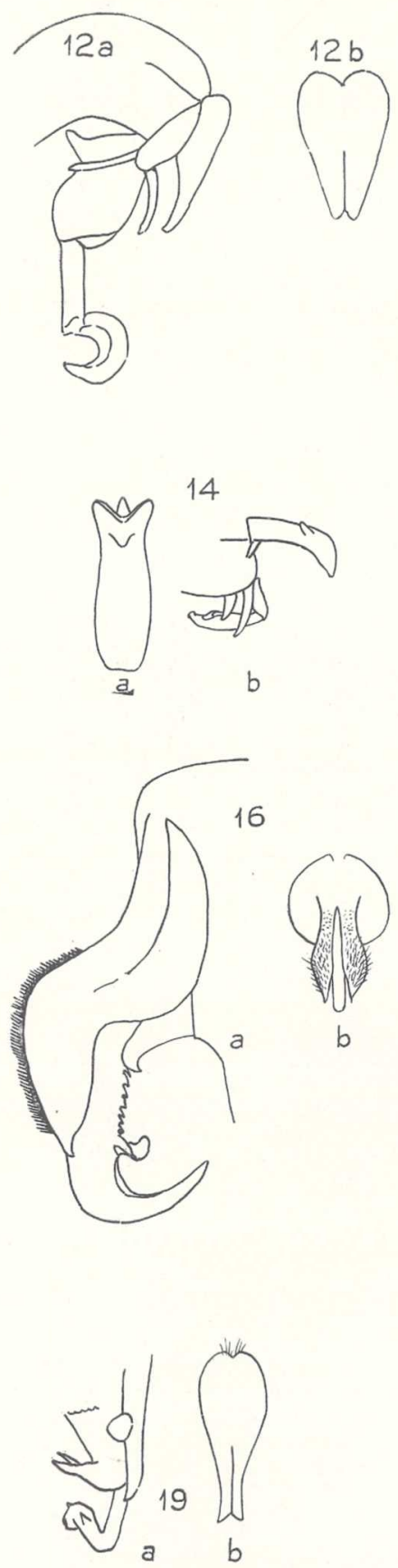

GeNitALIA OF FLiES OF THE GeNUS SARCOPHAGA

FOR EXPLANATION OF PLATE SEE PAGE 38.
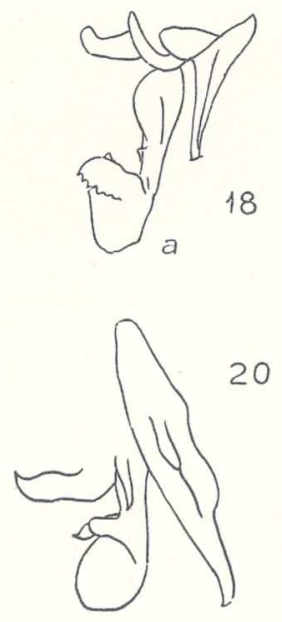

a

\section{5}
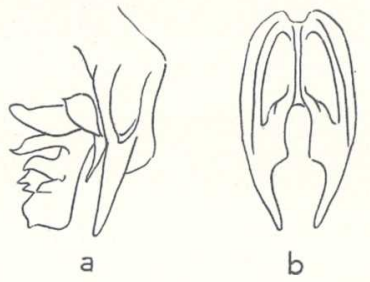

c
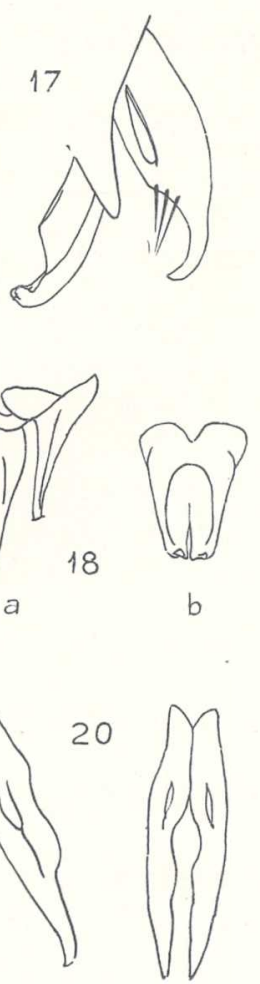

b 

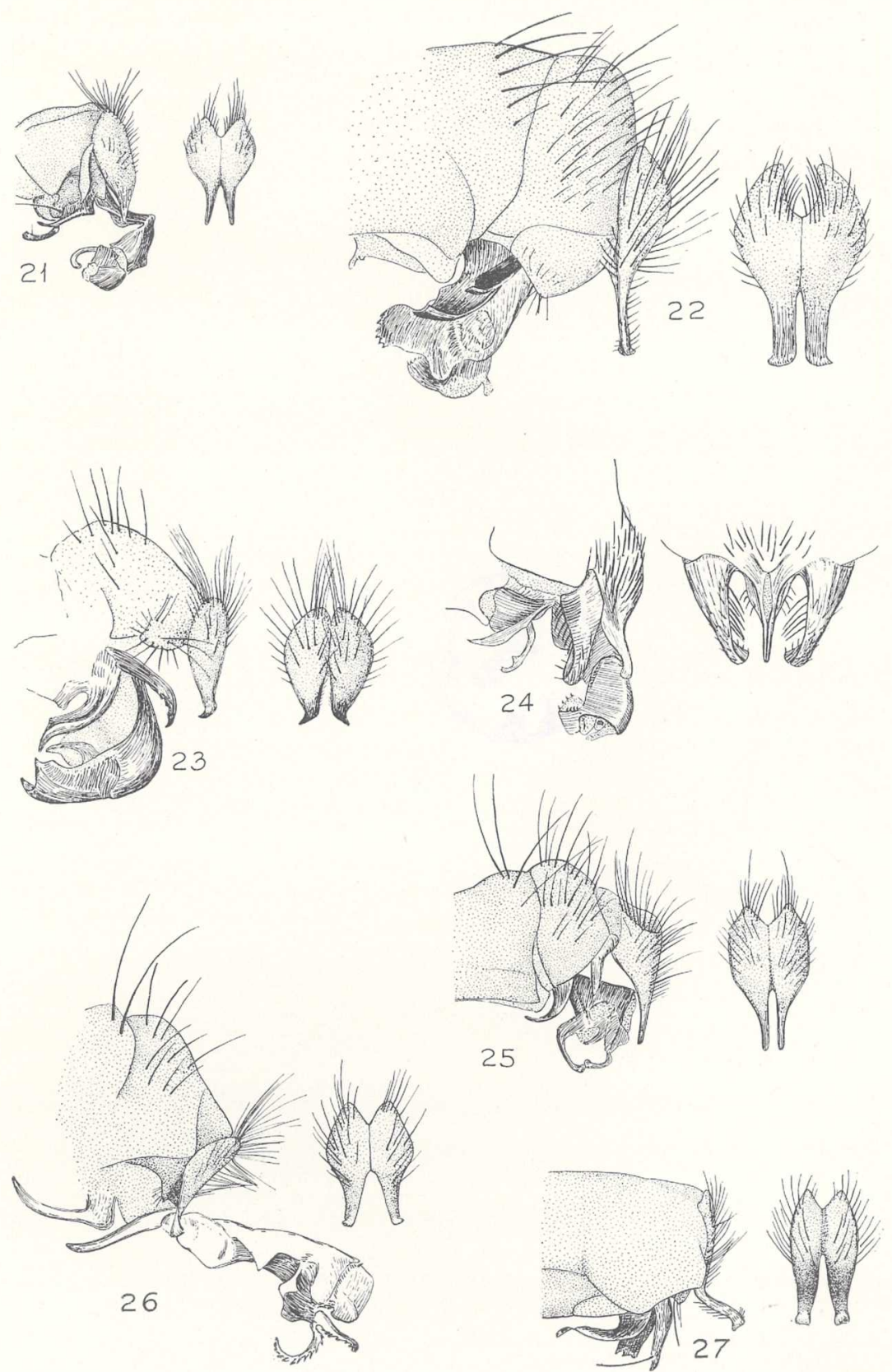

GENITALIA OF FLIES OF THE GENUS SARCOPHAGA

FOR EXPLANATION OF PLATE SEE PAGE 39. 


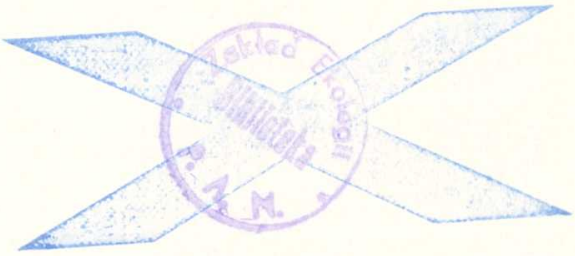

rcin.org.pl 
rcin.org.pl 


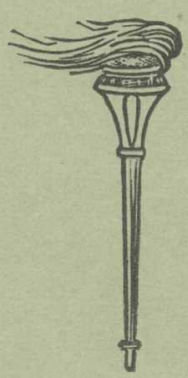

rcin.org.pl 